\title{
Age-stem diameter relationships of big sagebrush and their management implications
}

\author{
BARRY L. PERRYMAN AND RICHARD A. OLSON
}

Authors are assistant professor and associate professor, Department of Renewable Resources, University of Wyoming, Laramie, Wyo. 82071.

\begin{abstract}
Decisions to control big sagebrush (Artemisia tridentata Nutt.) on North American rangelands are traditionally based on morphological characteristics (e.g., cover) rather than more ecologically based community successional criteria. Big sagebrush stand age is a critical component for evaluating successional status, but has been difficult to obtain under field conditions. Assessing big sagebrush plant age based on stem diameter would provide resource managers with an efficient field tool to make management decisions based on ecological principles. For each of 3 subspecies of big sagebrush, between 75-80 stem cross-sections were collected within each of 9 stands situated at 3 regionally dispersed locations across Wyoming. Maximum basal stem diameters were measured and plant age determined from annual growth-ring assessments. Regression analysis (95\% confidence interval) relating maximum basal stem diameter to plant age produced coefficients of determination $\left(r^{2}\right)$ of $0.70,0.64$, and 0.61 for Wyoming big sagebrush (A. tridentata ssp. wyomingensis Beetle and Young) in each of 3 regional locations; $0.53,0.69$, and 0.64 for mountain big sagebrush $(A$. tridentata ssp. vaseyana [Rydb.] Beetle); and 0.50, 0.62, and 0.44 for basin big sagebrush (A. tridentata ssp. tridentata). Combined regional data for each subspecies produced $r^{2}$ values of 0.54 for Wyoming big sagebrush, 0.52 for mountain big sagebrush, and 0.50 for basin big sagebrush. Results indicate that maximum basal stem diameter can be used to assess the age of big sagebrush subspecies, thus, providing land managers with an ecologically based alternative method for justifying big sagebrush management decisions.
\end{abstract}

Key Words: big sagebrush, annual growth-rings, succession

All 3 subspecies of big sagebrush, basin big sagebrush (Artemisia tridentata Nutt. ssp. tridentata, mountain big sagebrush (A. tridentata subsp. vaseyana [Rydb.] Beetle), and Wyoming big sagebrush (A. tridentata subsp. wyomingensis Beetle and Young) are dominant constituents of many rangeland communities. Intensive livestock grazing during the first half of this century, periodic drought and recent wildfire suppression efforts have allowed big sagebrush to dominate more than 100 million acres of North American rangelands (Miller et al. 1994, Pieper 1994). Decisions to control big sagebrush are generally based on either the subjective condition of "when sagebrush stands are dense and tall" or the more quantitative condition

Research was funded in part by the Wyoming Abandonded Coal Mined-lands Research Program, University of Wyoming.

Manuscript accepted 17 Aug. 1999.

\section{Resumen}

Las decisiones de controlar la artemisa grande (Artemisia tri dentata Nutt.) en las praderas norte americanos tradicionalmente están basadas en las características morfológicas (e.g., la tapa) más bien que el criterio comunitario sucesivo que es más basada en la ecología. La edad situada de la artemisa grande es un componente crítico para evaluar el estatus sucesivo, pero ha sido difícil en obtener bajo de las condiciones del campo. Amillarar la edad de la artemisa grande a base del diámetro del tallo les proveería a los gerentes de recursos con una ventaja eficaz para hacer decisiones basadas en los principales ecológicos. Por cada una de las 3 subespecies de la artemisa grande, fueron coleccionados entre 75-80 tallos cuadriculados dentro de cada de las 9 plataformas situadas en 3 lugares regionalmente dispersados por Wyoming. Los diámetros máximos de los tallos basales fueron medidos y la edad de la planta fue determinada por el amillarar de los anillos anuales del crecimiento. El análisis regresado (de intervalo de confianza a $95 \%$ ) relacionando el diámetro máximo del tallo basa a la edad de la planta produjo coeficientes de determinación $\left(\mathrm{r}^{2}\right)$ de $0.70,0.64$, y 0.61 para la artemisa grande de Wyoming (A. tridentata ssp. wyomingenisis Beetle y Young) en cada de los tres lugares regionales; $0.53,0.69$, y 0.64 para la artemisa grande de la montaña $(A$. tridentata ssp. vaseyana [Rydb.] Beetle); y 0.50, 0.62 y 0.44 para la artemisa grande de la cuenca (A. tridentata ssp. tridentata). La data combinada de cada subespecie produjo los valores de $\left.r^{2} 0\right)$ de $0.70,0.64$, y 0.61 para la artemisa grande de Wyoming (A. tridentata ssp.wyomingenisis Beetle y Young) en cada de los tres lugares regionales; $0.53,0.69$, y 0.64 para la artemisa grande de la montaña (A. tridentata ssp. vaseyana [Rydb.] Beetle); y $0.50,0.62$, y 0.44 para la artemisa grande de la cuenca (A. tridentata ssp. tridentata). La data combinada de cada subespecie produjo los valores de $r^{2}$ de 0.54 para la artemisa grande de Wyoming, 0.52 para la artemisa grande de la montaña y 0.50 para la artemisa grande de la cuenca. Los resultados indican que el diámetro máximo del tallo basa se puede usar para amillarar la edad de las subespecies de la artemisa grande, entonces, les provee a los gerentes de la tierra con una manera alternativa basada ecológicamente para justificar las decisiones administrativas en cuanto a la artemisa grande.

"when sagebrush makes up more than one-half of the total plant cover," (Pechanec et al. 1954).

Recently, several rangeland ecologists have advocated the development and implementation of successional models that contain the concepts of multiple stable states, thresholds, and/or transition states, allowing opportunistic management strategies to be utilized in the manipulation of plant communities (Smith 1978, Archer et al. 1988, Westoby et al. 1989, Friedel 1991, 
Laycock 1991, and SRM Task Group on Unity in Concepts and Terminology 1995). Within these new models, the successional state of a given plant community is usually identified in terms of recovery time since the occurrence of some disturbance. Fire is one important disturbance process that drives successional changes in grassland/shrubland ecosystems (Wright and Bailey 1982). Fire suppression has been practiced since European settlement in almost all areas where grassland systems occur. On this basis, increased firereturn intervals have been cited as a primary cause of invasion and encroachment of fire-sensitive woody species into grasslands (Kucera 1981, Bock and Bock 1984, Wright and Bailey 1982, Fisher et al. 1987, Steinaur and Bragg 1987).

We believe that decisions to implement big sagebrush control practices should be based on ecological principles. A comparison of the age of a big sagebrush stand and the characteristic fire-return interval is an ecological approach related to the successional state of a given plant community. For example, if a particular stand of big sagebrush is 50 years old and the characteristic fire-return interval is 10 years, control practices should be implemented irrespective of the amount of big sagebrush cover.
Several investigators have used stem diameter to quickly predict the age of individuals or stands of woody plants. Hinchman and Birkeland (1995) developed age-stem diameter relationships for Fremont cottonwoods (Populus fremontii S. Wats.) in Utah and Arizona, to aid in dating fluvial surfaces such as channel bars in riparian environments. Brotherson et al. (1983) developed age-stem diameter relationships for 8 tree species in the Navajo National Monument, Arizona. These species included: box elder maple (Acer negundo L.), Utah juniper (Juniperus osteosperma utahensis [Torr.] Little), pinyon pine (Pinus edulis Engelm.), Fremont cottonwood, quaking aspen (Populus tremuloides Michx.), Douglas fir (Pseudotsuga taxifolia [Loudon] Britton), Gamble oak (Quercus gambelii Nutt.), and salt cedar (Tamarisk ramosissima Ledeb.). In another study, Brotherson et al. (1984) investigated age-stem diameter relationships of salt cedar in central Utah to assess invasion dynamics. Brotherson et al. (1980) also developed age-stem diameter relationships for 2 species of mountain mahogany (Cercocarpus montanus [Raf.] and Cercocarpus ledifolius [Nutt.]) from populations in Utah, Oregon, Nevada, and Wyoming. In each case, investigators found reasonable age-stem diameter rela- tionships for individuals within stands. However, the regression models were not consistent across stands or differing site potentials. Age-stem diameter relationships have not been developed for any subspecies of big sagebrush.

Ferguson (1964) demonstrated that annual growth-rings in big sagebrush were easily identified and reliable as a chronologic device. Given this characteristic, the purpose of this study was to determine if the age of big sagebrush plants could be predicted from maximum stem diameters. If big sagebrush plant or stand age can be quickly and accurately determined from maximum stem diameter, land managers will have a new method for identifying areas that are in a stable ecological state requiring sagebrush control. This is a more ecologically centered approach based on succession and fire frequency parameters rather than morphologic characteristics (e.g., cover) of big sagebrush plants.

Our specific objectives were: 1 ) determine if an accurate age to maximum basal stem diameter relationship existed for the 3 subspecies of big sagebrush; 2) determine if the relationship was stand specific within the same geographic region; and 3) determine if the relationship was consistent across a larger geographic area.

Table 1. GPS coordinates and elevations for all big sagebrush stands.

\begin{tabular}{|c|c|c|c|}
\hline Subspecies and location & latitude & longitude & elevation $(\mathrm{m})$ \\
\hline \multicolumn{4}{|l|}{ wyomingensis } \\
\hline \multirow[t]{2}{*}{ Northeast WY } & $43^{\circ} 34^{\prime} 20.439^{\prime \prime} \mathrm{N}$ & $105^{\circ} 10^{\prime} 24.033^{\prime \prime W}$ & 1538 \\
\hline & $43^{\circ} 35^{\prime} 20.184^{\prime \prime} \mathrm{N}$ & $104^{\circ} 52^{\prime} 02.262^{\prime \prime} \mathrm{W}$ & 1384 \\
\hline \multirow{2}{*}{ Central WY } & $43^{\circ} 10^{\prime} 02.433^{\prime \prime} \mathrm{N}$ & $106^{\circ} 35^{\prime} 46.319^{\prime \prime} \mathrm{W}$ & 1864 \\
\hline & $43^{\circ} 04^{\prime} 21.831 " \mathrm{~N}$ & $106^{\circ} 34^{\prime} 52.492 " \mathrm{~W}$ & 1899 \\
\hline Southwest WY & $42^{\circ} 52^{\prime} 07.327 " \mathrm{~N}$ & $109^{\circ} 57^{\prime} 53.668^{\prime \prime W}$ & 2295 \\
\hline \multicolumn{4}{|l|}{ vaseyana } \\
\hline \multirow[t]{3}{*}{ Southcentral WY } & $41^{\circ} 42^{\prime} 13.681^{\prime \prime} \mathrm{N}$ & $106^{\circ} 34^{\prime} 14.926^{\prime \prime} \mathrm{W}$ & 2244 \\
\hline & $41^{\circ} 42^{\prime} 19.279 " \mathrm{~N}$ & $106^{\circ} 34^{\prime} 03.639^{\prime \prime} \mathrm{W}$ & 2247 \\
\hline & $41^{\circ} 42^{\prime} 38.414 " \mathrm{~N}$ & $106^{\circ} 33^{\prime} 26.978^{\prime \prime} \mathrm{W}$ & 2269 \\
\hline \multirow[t]{3}{*}{ Central WY } & $43^{\circ} 55^{\prime} 30.500 " \mathrm{~N}$ & $106^{\circ} 45^{\prime} 30.500 " \mathrm{~W}$ & 2530 \\
\hline & $43^{\circ} 51^{\prime} 15.144 " \mathrm{~N}$ & $106^{\circ} 35^{\prime} 45.100^{\prime \prime} \mathrm{W}$ & 2591 \\
\hline & $43^{\circ} 30^{\prime} 10.500 " \mathrm{~N}$ & $106^{\circ} 28^{\prime} 30.575^{\prime \prime} \mathrm{W}$ & 2743 \\
\hline \multirow[t]{3}{*}{ Central WY } & $44^{\circ} 59^{\prime} 04.103 " \mathrm{~N}$ & $108^{\circ} 15^{\prime} 37.742^{\prime \prime} \mathrm{W}$ & 1500 \\
\hline & $44^{\circ} 01^{\prime} 25.918^{\prime \prime} \mathrm{N}$ & $108^{\circ} 00^{\prime} 40.873^{\prime \prime} \mathrm{W}$ & 1276 \\
\hline & $44^{\circ} 02^{\prime} 44.150 " \mathrm{~N}$ & $108^{\circ} 04^{\prime} 02.211^{\prime \prime W}$ & 1222 \\
\hline \multirow[t]{3}{*}{ Southwest WY ${ }^{1}$} & $42^{\circ} 53^{\prime} 32.871 " \mathrm{~N}$ & $110^{\circ} 08^{\prime} 10.433^{\prime \prime} \mathrm{W}$ & 2232 \\
\hline & $42^{\circ} 47^{\prime} 24.146 " \mathrm{~N}$ & $110^{\circ} 01^{\prime} 02.187^{\prime \prime W}$ & 2151 \\
\hline & $42^{\circ} 45^{\prime} 13.367 " \mathrm{~N}$ & $110^{\circ} 03^{\prime} 39.924^{\prime \prime} \mathrm{W}$ & 2229 \\
\hline \multirow[t]{3}{*}{ Southwest WY ${ }^{2}$} & $42^{\circ} 47^{\prime} 30.161^{\prime \prime} \mathrm{N}$ & $109^{\circ} 57^{\prime} 49.956^{\prime \prime} \mathrm{W}$ & 2104 \\
\hline & $42^{\circ} 47^{\prime} 57.983 " \mathrm{~N}$ & $109^{\circ} 57^{\prime} 48.782^{\prime \prime W}$ & 2119 \\
\hline & $42^{\circ} 48^{\prime} 02.694 " \mathrm{~N}$ & $109^{\circ} 57^{\prime} 46.575^{\prime \prime W}$ & 2108 \\
\hline
\end{tabular}

${ }^{\mathrm{T}}$ West slope of the Green River Basin

${ }^{2}$ East slope of the Green River Basin 


\section{Methods}

Big sagebrush stands having a variety of cohorts, similar soil characteristics and topography, and relatively free from herbivory disturbance were selected for this study. Sites were selected to minimize microsite effects that increase or decrease supplemental moisture conditions. This approach minimized variations in growth rates between sites (Bonham et al. 1991).

Stem sections for subspecies wyomin gensis were collected from 3 stands in northeast Wyoming near Rochelle; 3 stands in the South Fork of the Powder River watershed, northwest of Casper in central Wyoming; and 3 stands in southwest Wyoming near Pinedale. Stem sections for the subspecies tridentata were collected from 3 stands near Pinedale; 3 stands near Worland, on the west slope of the Bighorn Mountains; and 3 stands near Farson, in southwest Wyoming. Stem sections for the subspecies vaseyana were collected from 3 stands near Pinedale; 3 stands near Buffalo, on the east slope of the Bighorn Mountains; and 3 stands west of Laramie, near Elk Mountain in south central Wyoming. The 3 stands in each regional grouping were located within a 15 mile radius. All stand locations were permanently recorded with a Global Positioning System, and latitude/longitude coordinates and elevations are listed in Table 1.

A stratified, random sampling method was used to collect stem cross-sections from each sagebrush stand. A permanent baseline transect $100 \mathrm{~m}$ long was located within each sagebrush stand, and ten, 100 $\mathrm{m}$ long perpendicular transects were established at randomly selected points along the baseline transect. Along each perpen- dicular transect, 8 random points were selected, and the closest individual big sagebrush plant was selected for sampling. If the closest individual was not suitable for aging (e.g., damaged stem), another random point was selected until a suitable individual was encountered.

Stem cross-sections were obtained by sawing the plant off below ground level (Ferguson 1964) to ensure that the pith and first annual growth ring were included. The stem was then cut approximately $10 \mathrm{~cm}$ from the bottom, providing a $10 \mathrm{~cm}$ long stem section. Sampling was conducted during the summer of 1997. Between 75 and 80 stem sections were collected from each stand (Cawker 1980).

In the laboratory, the bottom portion of each stem section was sanded sequentially with $60,80,320$, and 400 grit sanding belts. Annual growth-rings were examined using a 10 power stereo microscope, and enumerated once by 2 different technicians for a total of 2 observations per sample.

Basal stem diameters were measured at the widest point across the face of each cross-section. Maximum basal stem diameter was designated the dependent variable, and age the predictor variable in simple linear regression analyses (Steel and Torrie 1980).

Regression models were constructed at 3 geographic scales. A model was constructed for each subspecies stand and for each group of 3 stands within the same relative geographic region. A comprehensive model for each subspecies was also constructed by combining all stands of the same subspecies to assess statewide consistency. All regression analyses were performed with the Microsoft Excel Version 7.0 Statistics Module.

\section{Results and Discussion}

Annual growth rings were easily identified making crossdating unnecessary. False rings have never been encountered in big sagebrush in northern latitudes and at higher elevations (Diettert 1938, Moss 1940, Ferguson 1964). Global position and elevation of Wyoming fulfill both of these criteria. Locally absent rings do occur, however complete absence of rings are almost never encountered due to the unique nature of annual ring formation in big sagebrush.

The annual growth-ring in big sagebrush is formed by an interxylary cork layer rather than increasing cell density bands as in most tree species. By nature, this makes the creation of interannual bands impossible. "This cork layer is produced during the growing season, between the new annual wood ring and that of the previous year. With the beginning of growth in the spring a single layer of meristematic cells (the interxylary cork cambium) remains between the last-formed xylem of the previous year and the newly forming xylem tissue. With the onset of hot and dry weather, the innermost layer of these cells becomes suberized" (Ferguson 1964).

Simple linear regression of the number of annual growth-rings against maximum basal stem diameter yielded significant equations $(\mathrm{p}<0.0001)$ for all 27 individual stands, all 9 regional stand combinations, and all 3 statewide combinations. The coefficient of determination for individual stands ranged from 0.22 to $0.73 ; 0.44$ to 0.70 for regional stand combinations; and 0.50 to 0.54 for statewide combinations (Table 2). Ranges and means for maximum diameter and age by subspecies are listed in Table 3. The residuals for each regression model had normal distributions.

Table 2. Age prediction equations for each individual big sagebrush subspecies by regional stand locations along with coefficients of determination $\left(\mathbf{r}^{2}\right)$, sample numbers $(\mathbf{n})$, and p-values.

\begin{tabular}{|c|c|c|c|c|c|}
\hline Subspecies and Location & Age prediction equation & $\overline{r^{2}}$ & $\mathrm{n}$ & p-value & $95 \% \mathrm{CI}$ \\
\hline $\begin{array}{l}\text { wyomingensis } \\
\text { Northeast WY } \\
\text { Central WY } \\
\text { Southwest WY }\end{array}$ & $\begin{array}{l}\text { Age }=5.6910+0.6744(\text { diameter }) \\
\text { Age }=16.6392+0.9404(\text { diameter }) \\
\text { Age }=5.4648+0.8514(\text { diameter })\end{array}$ & $\begin{array}{l}0.70 \\
0.64 \\
0.61\end{array}$ & $\begin{array}{l}220 \\
199 \\
181\end{array}$ & $\begin{array}{l}0.0001 \\
0.0001 \\
0.0001\end{array}$ & $\begin{array}{l} \pm 0.12 \\
\pm 0.20 \\
\pm 0.29\end{array}$ \\
\hline $\begin{array}{l}\text { vaseyana } \\
\text { Southcentral WY } \\
\text { Central WY } \\
\text { Southwest WY }\end{array}$ & $\begin{array}{l}\text { Age }=1.4846+0.6819(\text { diameter }) \\
\text { Age }=5.6688+0.4430(\text { diameter }) \\
\text { Age }=7.8955+0.8830(\text { diameter })\end{array}$ & $\begin{array}{l}0.53 \\
0.69 \\
0.64\end{array}$ & $\begin{array}{l}211 \\
229 \\
191\end{array}$ & $\begin{array}{l}0.0001 \\
0.0001 \\
0.0001\end{array}$ & $\begin{array}{l} \pm 0.18 \\
\pm 0.08 \\
\pm 0.19\end{array}$ \\
\hline $\begin{array}{l}\text { tridentata } \\
\text { Central WY } \\
\text { Southwest WY } \\
\text { Southwest WY }\end{array}$ & $\begin{array}{l}\text { Age }=6.3189+0.3783(\text { diameter }) \\
\text { Age }=4.9916+0.3543(\text { diameter }) \\
\text { Age }=6.1918+0.3020(\text { diameter })\end{array}$ & $\begin{array}{l}0.50 \\
0.62 \\
0.44\end{array}$ & $\begin{array}{l}229 \\
223 \\
212\end{array}$ & $\begin{array}{l}0.0001 \\
0.0001 \\
0.0001\end{array}$ & $\begin{array}{l} \pm 0.10 \\
\pm 0.07 \\
\pm 0.09\end{array}$ \\
\hline
\end{tabular}

${ }^{1}$ West slope of the Green River Basin

${ }^{2}$ East slope of the Green River Basin 


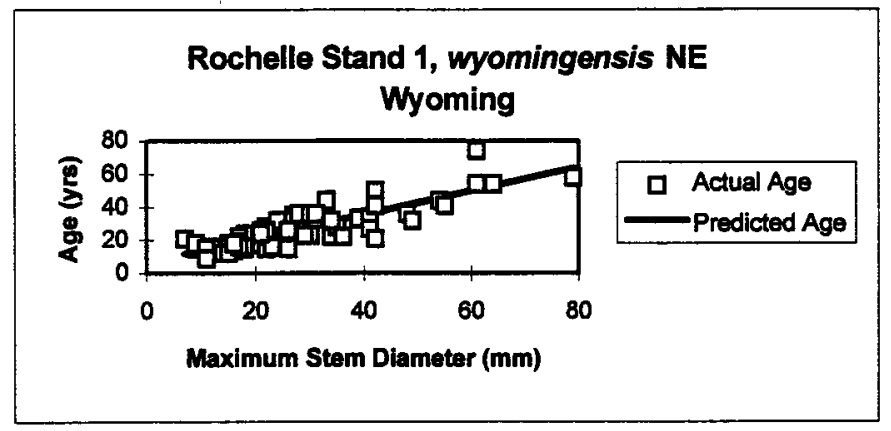

$6.810+0.7194$ (diameter), $r^{2}=0.73$

Fig. 1. A representative scatter plot for subspecies wyomingensis at the individual stand scale.

All samples including those which seemed to be outliers were included in the analyses. The effect of outliers is insignificant considering the large sample sizes incorporated in each model. Inclusion of potential outliers also provides models that are similar to conditions actually encountered in the field. A representative scatter plot for subspecies wyomingensis at the stand scale is shown in Fig. 1. Differences in intercept values were generally small between individual stands, regional stand combinations, and statewide combinations within the same subspecies, and ranged from 1 to 17 years. Confidence intervals (95\%) around the population means ranged from \pm 0.10 to \pm 0.48 for individual stands; \pm 0.07 to \pm 0.29 for regional stand combinations; and \pm 0.06 to \pm 0.14 for statewide combinations. Coefficient of determination values indicate that maximum stem diameter can predict the age of big sagebrush plants. The relationship was stronger for Wyoming and mountain big sagebrush than for basin big sagebrush at the stand and regional stands of basin big sagebrush showed very strong relationships $(0.75$ and 0.71 coefficients of determination). We believe that because basin big sagebrush often occurs in areas where groundwater can be relatively shallow, some individual plants may be accessing a reliable groundwater source deep in the soil profile resulting in differencombination scales. However, 2 individual

tial growth rates from plants not able to access the additional moisture. In areas where this additional moisture is not available, the age-stem diameter relationship appears to be similar to the other 2 subspecies.

The relationships are almost identical at the statewide scale. At this large spatial scale, coefficient of determination values were 0.54 for Wyoming big sagebrush, 0.52 for mountain big sagebrush, and 0.50 for basin big sagebrush. This is a predictable response when combining data sampled from areas that have significant variations in precipitation timing and amount, and growing season temperatures and lengths. Our models demonstrated efficacy at the stand and regional stand combination scales, however, inter-stand variations do exist. Our method has limitations similar to estimating aboveground biomass production with Robel et al. (1970) or other vegetation height-weight relationship methods. An initial regression model must be constructed before application to larger geographic areas. Once initial baseline models are generated for an area, maximum stem diameter measurements could serve as a useful tool for predicting big sagebrush stand ages.

Results from this study have several implications for management. Based on our developed regression models, land managers could quickly assess the age of big sagebrush stands by measuring maxi-

Table 3. Ranges and means for maximum stem diameter and age by subspecies.

\begin{tabular}{|c|c|c|c|c|c|c|}
\hline \multirow[t]{2}{*}{ Subspecies } & \multicolumn{3}{|c|}{ Diameter } & \multicolumn{3}{|c|}{ Age } \\
\hline & Minimum & Maximum & Mean & Minimum & Maximum & Mean \\
\hline & \multicolumn{3}{|c|}{$\ldots \ldots-\ldots \ldots-\ldots(\mathrm{mm})-\ldots \ldots \ldots$} & \multicolumn{3}{|c|}{$\ldots \ldots \ldots \ldots$ (years) $\ldots \ldots \ldots$} \\
\hline wyomingensis & 3 & 75 & 27.6 & 3 & 75 & 31.7 \\
\hline vaseyana & 5 & 82 & 27.3 & 3 & 79 & 23.4 \\
\hline tridentata & 2 & 145 & 29.5 & 3 & 54 & 16.0 \\
\hline
\end{tabular}

mum basal stem diameter of the largest individual plants in a stand. Stand age could then be compared with fire frequency information to determine if control practices should be implemented. This ecologically based assessment provides stronger justification for management decisions. Likewise, this approach will clarify the successional state (if stable state successional models are applicable) of any big sagebrush stand for satisfying land use management objectives in any situation.

\section{Literature Cited}

Archer, S., C.J. Scifres, and C.R. Bassham. 1988. Autogenic succession in subtropical savanna: conversion of grassland to thorn woodland. Ecol. Mono., 58:111-127.

Bock, H.H. and C.E. Bock. 1984. The effects of fire on virgin northern mixed grassland at Custer Battlefield National Monument. NPS Research Center, Laramie, Final Report.

Bonham, C.D., T.R. Cottrell, and J.F. Mitchell. 1991. Inferences for life history strategies of Artemisia tridentata subspecies. J. Vegetat. Sci., 2:339-344.

Brotherson, J.D., J.G. Carman, and L.A. Szyska. 1984. Stem-diameter age relationships of Tamarix ramosissma in Central Utah. J. Range Manage., 37:362-364.

Brotherson, J.D., J.N. Davis, and L. Greenwood. 1980. Diameter-age relationships of two species of mountain mahogany. J. Range Manage., 33:367-370.

Brotherson, J.D., S.R. Rushforth, W.E. Evenson, J.R. Johansen and C. Morden. 1983. Population dynamics and age relationships of 8 tree species in Navajo National Monument, Arizona. J. Range Manage., 36:250-256.

Cawker, K.B. 1980. Evidence of climatic control from population age structure of Artemisia tridentata Nutt. in southern British Columbia. J. Biogeogr., 7:237-248.

Diettert, R.A. 1938. The morphology of Artemisia tridentata Nutt. Lloydia, 1:3-74.

Ferguson, C.W. 1964. Annual Rings in Big Sagebrush. Papers of the Laboratory of TreeRing Research, No. 1. Univ. of Arizona Press, Tuscon, Ariz. 95p.

Fisher, R.F., J.J. Jenkins, and W.F. Fisher. 1987. Fire and the prairie-forest mosaic of Devil's Tower National Monument. Amer. Midl. Nat., 117:250-257.

Friedel, M.H. 1991. Range condition assessment and the concept of thresholds. A viewpoint. J. Range Manage., 44:422-426.

Hinchman, V.H. and K.W. Birkeland. 1995. Age prediction based on stem size for riparian cottonwood stands. The Southw. Nat., 40:406--409.

Kucera, C.L. 1981. Grasslands and fire. In: Fire Regimes and Ecosystem Properties. U.S.D.A. For. Serv. Gen. Tech. Rep. WO-26, 594p. 
Laycock, W.A. 1991. Stable states and thresholds of range condition on North American rangelands: A viewpoint. J. Range Manage., 44:427-433.

Miller, R.F., T.J. Svejcar, and N.E. West. 1994. Implications of livestock grazing in the intermountain sagebrush region: Plant composition, pp. 101-146. In: M. Vavra, W.A. Laycock, and R.D. Pieper (eds.), Ecological implications of livestock herbivory in the West. Society for Range Management, Denver, Colo.

Moss, E.H. 1940. Interxylary cork in Artemisia with reference to its taxonomic significance. Amer. J. Bot., 27:762-68.

Pechanec, J.F., G. Stewart, A.P. Plummer, J.H. Robertson, and A.C. Hull Jr. 1954. Controlling sagebrush on rangelands. USDA Farmer's Bull. No. 2072, Washington D.C. U.S. Gov. Printing Office, pp. 4-8.
Pieper, R.D. 1994. Ecological implications of livestock grazing. pp. 177-211. In: M. Vavra, W.A. Laycock, and R.D. Pieper (eds.), Ecological implications of livestock herbivory in the West. Soc. for Range Management, Denver, Colo.

Robel, R.J., J.N. Briggs, A.D. Dayton, and L.C. Hulbert. 1970. Relationships between visual obstruction measurements and weight of grassland vegetation. J. Range Manage., 22:295-297.

Smith, E.L. 1978. A critical evaluation of the range condition concept. Inter. Natl. Rangeland Conf. Proc. 1st. Denver, Colo. p. 266-267.

SRM Task Group on Unity in Concepts and Terminology. 1995. New concepts for assessment of rangeland condition. J. Range Manage., 48:271-283.
Steel, R.G.D. and J.H. Torrie. 1980 . Principles and Procedures of Statistics: A Biometrical Approach, 2nd Ed. McGrawHill, New York.

Steinauer, E.M. and T.B. Bragg. 1987. Ponderosa pine (Pinus ponderosa) invasion of Nebraska Sandhills prairie. Amer. Midl. Nat., 118:358-365.

Westoby, M., B. Walker, and I. Noy-Meir. 1989. Opportunistic management for rangelands not at equilibrium. J. Range Manage., 42:266-274.

Wright, H.A. and A.W. Bailey. 1982. Fire Ecology: United States and Canada. John Wiley and Sons, New York. 